\title{
The First International in Latin America
}

\author{
Horacio Tarcus \\ Translation from Spanish by Bécquer Medak-Seguín
}

\section{Introduction}

For the past half century, the strength and even the existence of the First International in Latin America has remained a moot point for historians. In his 1964 contribution to the Colloque International sur La Première Internationale, Uruguayan historian Carlos Rama attempted to document the existence of International Working Men's Association (IWMA) branches in Martinique, Guadeloupe, Havana, Río de Janeiro, Mexico City, Buenos Aires, and Santiago. So weak was the documentary evidence that the Rev. Paul Droulers (s.J.), one of the participants, asked him if "in Latin America, as in other places, the International had not been but a myth." Rama understood the "value of myth" in the Sorelian sense and replied that, indeed, "the International represented for the workers the hope of finding in Europe support for their struggles."

Eight years later, the Chilean Marcelo Segall strove in his turn to document the existence of branches of the International in Santiago and Valparaiso (1972), only to be given the lie by a historian of the following generation, Sergio Grez Toso, who wrote in his thesis on the genesis of socialism in Chile: "there is no serious sign, much less proof, of an organized action of the International in this country." Furthermore, Sergio Grez Toso didn't hesitate to describe its phantasmagoric presence as a myth "persistent and relatively impermeable to the most elemental historical evidence". ${ }^{2}$

Nevertheless, five years later an Ecuadorian historian published the thick volume, La I Internacional en Latinoamérica. In spite of its promising title, the author Plutarco Naranjo, who was not cognizant of the works of Rama and Segall, was quick to warn that he knew of no influence of the First International in Latin America outside of Ecuador. ${ }^{3}$ And even the documentary evidence

1 Carlos M. Rama, "L’Amérique Latine et la Première Internationale", in AAvv, La Première Internationale. L' Institution, l' implantation, le rayonnement (Paris, 1968), p. 426.

2 Sergio Grez Toso, De la "regeneración del pueblo" a la huelga general. Génesis y evolución histórica del movimiento popular en Chile (1810-189o) (Santiago de Chile, 1998), p. 519.

3 Plutarco Naranjo, La I Internacional en Latinoamérica (Quito, 1977) p. 10.

(C) HORACIO TARCUS, 2018 | DOI 10.1163/9789004335462_017

This is an open access chapter distributed under the terms of the prevailing CC-BY-NC License. 
pertaining to the Ecuadorian experience was weak: all he had to offer was a speech by the essayist Juan Montalvo delivered in Quito in 1876 concerning the foundation of the Republican Society, an antidictatorial association that, according to him, was organized in accordance with the IWMA statutes, thereby constituting "the first attempt to adapt the First International to the climate of Latin America." As additional proof, Naranjo transcribed articles from the conservative press denouncing Montalvo as a communist and the Republican Society as a local branch of the frightening International. ${ }^{4}$ Naranjo's interpretation was criticized by Noël Salomon at a conference held in Besançon (1975), where Salomon underlined that Montalvo had only spoken of the International as an example of the voluntary nature of worker's associations: it's "an International at Montalvo's disposition, related to his liberalism, Christianity, and anticlerical Erasmism." Montalvo had also affirmed that the International would respect property and had criticized the experience of the Commune. Montalvo's conception of the International, concluded Salomon, "responds to a generous idea, a chivalrous, Quixotic sensibility; his adversaries are the ones who inscribe him completely within the International". ${ }^{5}$

Should then Grez Toso's judgement be extended to the whole continent, and should we conclude, as Droulers suggested, that the presence of the International in Latin America was simply a myth, a specter that frightened the dominant elites and provided a faint hope for a handful of exiled Europeans? In this paper, I will focus on the branches of the International in Mexico City, Montevideo, and Buenos Aires, for which some documentary evidence exists. Due to lack of space, the references to the International in both the "bourgeois" and the burgeoning workers' Latin American press will be left aside.

\section{The International in Mexico}

News of the creation of the International arrived in a Mexico that, since the 1850s, had sheltered workers' societies of a mutualist nature. A flyer distributed in Mexico toward the end of 1870 outlined the Statutes of the International approved by the Geneva Congress, which had called for these societies to unite. At the bottom of this flyer could be read: "It's our turn, Mexican workers, to carry out our national unity". ${ }^{6}$ The leaders of the workers' societies agreed to

4 Ibid., p. 173 .

5 Plutarco Naranjo, "Montalvo y la Primera Internacional en el Ecuador", in Juan Montalvo en Francia (Paris, 1976), pp. 221-222.

6 José C. Valadés, El socialismo libertario mexicano (siglo XIX). Prólogo de Paco Ignacio Taibo II (Culiacán, 1984), p. 49. 
hold a series of meetings and, on 10 January 1871, an invitation was sent out to the associations to designate three delegates each. The Gran Círculo de Obreros, the first trade union federation in Mexico, was subsequently established on this basis in 1871 by a handful of printers and tailors. By 1876 it included thousands of affiliates organized into twenty-nine associations distributed across the country.

Not long after, the weekly El Socialista appeared in Mexico City on 9 July 1871. This paper was published until 1888 as the organ of the Gran Círculo. Open to all tendencies, it regularly informed its readers about the activities of the International. One of its editors, Mariano García, defended the Paris Commune and hailed the International: "terror of the tyrants, hope of the future!". ${ }^{7}$ In its 10 September 1871 issue, the paper published the Statutes of the International. Years later, on 12 July 1884, it would print the first Latin American edition of The Communist Manifesto.

Parallel to the foundation of the Gran Círculo, an immigrant of Greek origins, Plotino Rhodakanaty, influenced first by Fourier and later by Proudhon, created together with a group of youths a society called La Social in March of 1871. Against the socialist mutualism of the Gran Círculo's artisans, which sought the support of liberal presidents in the face of large-scale industry, $L a$ Social proclaimed "the abolition of any system of government." ${ }^{8}$ One of its affiliates, Santiago Villanueva, presided over the Gran Círculo, but, after his death in 1872 , the leadership fell into the hands of a socialist mutualist, the printer Juan de Mata Rivera, who had been accused of being "the representative in those regions of Mr. Marx" by the Uruguayan internationalists related to the Jura federation of the International. ${ }^{9}$ This was undoubtedly an exaggeration deriving from political rivalries. Mata Rivera had evolved at the time from mutualist ideas toward a socialism with a co-operativist and reformist inclination. He directed the weekly El Socialista (1871-1888), in which he declared himself time and again a partisan of the coalition between Capital and Labor, and called for presidential patronage for the incipient worker's movement, even thought he also published texts of a more radical nature.

7 César García Cantú, El socialismo en México (siglo XIX) (México, 1969), p. 74.

8 Valadés, El socialismo libertario, p. 50. See also Plotino C. Rhodakanaty, Obras. Edición, prólogo y notas de Carlos Illades, recopilación María Esther Reyes Duarte (México, 1998) and Carlos Illades, Las otras ideas. El primer socialismo en Mexico, 1850-1935 (México, 2008), particularly pages $37-40,155^{-80}$.

9 Valadés, "Sobre los orígenes del movimiento obrero en México. Apéndice. Documentos para la historia del anarquismo en América", in AAvv, Certamen internacional de La Protesta (Buenos Aires, 1927), p. 84. 
The Gran Círculo and its organ, El Socialista, were corresponding with the General Council in London. After the Hague Congress, ties were maintained with the General Council of New York and the Jura federation..$^{10}$ It was mostly the antipolitical socialists of La Social who maintained correspondence with the Jura federation as well as with the Uruguayan section of Montevideo. ${ }^{11}$ Thanks to a letter written by the Internationalists of Montevideo, we know that the "antipolitical" Mexicans of La Social applied for membership in the International through the Regional Spanish Federation, and that the Bern Congress granted that satisfaction to them. ${ }^{12}$ The antipolitical elements also launched more radical newspapers, such as La Comuna (1874), La Huelga (1875), El Hijo del Trabajo (1876) and La Internacional (1878).

The discord between the "political" and "antipolitical" tendencies in Mexico led to a confrontation years after the Hague Congress. In 1876, when the Gran Circulo summoned the Gran Congreso Obrero, orators of both tendencies faced one another. For Valadés, this echoed the scission that had taken place four years before in the International. García Cantú expressed a more nuanced opinion: accepting that "the Jura federation, through Spain and Montevideo, had hatched its plot in Mexico City" and that the Bakuninists had spread propaganda in the city through Zalacosta, he nevertheless insisted that the emergence of anarchism in Mexico ought to be dated from a later period, that of the brothers Flores Magón, in the late nineteenth and early twentieth centuries. ${ }^{13}$ The tensions that existed at the time within the Mexican organizations (political struggle v. abstention; mutualism v. cooperativism; opposition v. collaboration between Capital and Labor) had preceded the debates in the International. If Mata Rivera was not "Marx's man in Mexico", nor was La Social Bakuninist, regardless of its ties to the Jura federation. "Its leader, Rhodakanaty, was a Christian socialist. From anarchism, he only retained the opposition to the State and the conviction that the great act of a social liquidation would come from the will of all workers in the inauguration of a more just society." In sum, if the split in the International had an impact on the Mexican workers, it was only indirectly, by superimposing itself on prior antagonisms. All in all, García Cantú concluded, the International had stimulated the will to unify "the harassed artisan with a budding proletarian". ${ }^{14}$

$10 \quad$ Valadés, El socialismo libertario, pp. 74-75; James Guillaume, L'Internationale. Documents et souvenirs, 4 vol. (Paris, 1909), vol. 3, p. Xv; (Paris, 1910), vol. 4, p. 140.

11 Valadés, "Sobre los orígenes", pp. 87-88.

12 Ibid., pp. 87-88.

13 García Cantú, El socialismo en México, p. 186.

14 Ibid., p. 187. 


\section{The International in Montevideo}

In Uruguay too the emergence of a mutualist movement had preceded trade organization and working class politics. The Montevidean Typographic Society was founded in 1870, and three years later it signed a pact of "reciprocal unity" with the Typographic Society of Buenos Aires. In 1883, they launched El Tipógrafo, the first trade unionist newspaper in Uruguay.

Through the correspondence edited by José C. Valadés, we know that a Uruguayan section of the International was established in Montevideo in 1872, which got in touch with La Social in Mexico and the Spanish Regional Federation. Its secretary was Francisco C. Galcerán, a Catalan migrant who, in an 1873 letter, wrote of the "sworn loyalty to the Socialist Democratic Alliance" (referring to the association created by Bakunin in Geneva in 1868). And thanks to a letter sent from Montevideo by an Internationalist named A. Juanes, probably another Spanish immigrant, we know that they were confronting "London agents" and that, since 1872, they had been aware of the "Machiavellianism of the General Council in London against Bakunin".15

The Uruguayan section called a workers assembly in Montevideo on 27 June 1875. That day saw the foundation of the Regional Federation of the Oriental Republic of Uruguay, also called the Montevidean Federation (it never expanded beyond the capital city). The meeting was a success, since nearly 2,00o people attended it at a time when the number of workers didn't exceed 20,000 in Montevideo. ${ }^{16}$ Not long after the founding of the Federation, on 7 July 1875 , a leaflet titled "Manifesto for All the Workers of Montevideo" was published. It asserted the productive character of labor ("without the worker, no society could exist") and called on workingmen to turn a deaf ear to the "able style" of the exploiters since "our redemption must be the work of ourselves." ${ }^{17}$ The workers of Montevideo, the leaflet went on, should unite considering the "beneficial results" obtained "all over the world [by] the International." The address had a class character (capital is designated as the enemy of the worker), but the government, far from being attacked, was presented as the guarantor of the Liberal Constitution: "Residents of a republican country, whose laws are especially democratic, and, where therefore, freedom of association is a given, let us constitute ourselves in the shadows of this philanthropic system, since the Government will be attentive not to suppress in the least our aspirations." The

\footnotetext{
15 Valadés, "Sobre los orígenes", p. 84.

16 Fernando López D’Alessandro, Historia de la izquierda uruguaya. 1. Anarquistas y socialistas (1838-1910), (Montevideo, 1994), p. 48.

17 Valadés, "Sobre los orígenes", pp. 86-87.
} 
"Manifesto," which ended with "Health, Work, and Justice," is signed by a "commission" composed of two bricklayers, three carpenters, a day laborer, a tailor and two others whose profession was not mentioned..$^{18}$

It would be excessive to present the Internationalists of Montevideo as "Bakuninists" from the contents of this text. Rather than considering the liberal government as their enemy, its authors placed themselves under its patronage. They also advocated the organization of all workers, regardless of their religious beliefs or political positions.

Yet, this did not stop them from corresponding with the "antipolitical" Mexicans of La Social, nor from sending a copy of the leaflet to the "Citizen Secretary of the Mexican Section of the International Workingmen's Association, brother Zalacosta" requesting publicity in the Mexican press. The "Manifesto" was republished in its entirety in El Socialista in Mexico on 17 October 1875. Although the men of La Social had intercepted a letter sent from Montevideo to Juan de Mata Rivera, arguing that he was not "a worthy party member" but rather "a businessman and a politician",19 the director of El Socialista gladly published the Manifesto received from a worker in Montevideo which not only praised the liberal government but also situated itself under its patronage.

Guillaume mentions the surprise of the Jura federation upon discovering the existence of the so-called Montevideo branch in the pages of a Mexican weekly. ${ }^{20}$ After that, the men of Montevideo exchanged press and correspondences with those of the Jura federation. Thanks to Nettlau, we know that a former Communard who had joined the Uruguayan section, Pierre Bernard, received in Montevideo the Bulletin de la Fédération jurassienne. ${ }^{21}$ We also know that the eighth General Congress of the International held in Bern on October 26-29 1876, received word from the Montevideo section. ${ }^{22}$ The Bulletin de la Fédération jurassienne, dated 22 April 1877, published for the first time a letter sent by the Comité de la Sociedad Internacional de Obreros in Montevideo, saying: "We regularly receive the Bulletin and we have also received the

\footnotetext{
18 Ibid., pp. 86-87.

19 Ibid., p. 84.

20 Guillaume, L'Internationale, vol. 3, p. 306.

21 Max Nettlau, "La Internacional en Buenos Aires en 1872-1873", in Suplemento Semanal de La Protesta (Buenos Aires, La Protesta, 15 de noviembre de 1926), p. 9. See also: Max Nettlau, "Más sobre la Internacional en Buenos Aires; algunas noticias de los años 1870-1873", Suplemento Quincenal de La Protesta (Buenos Aires, La Protesta, 20 de enero de 1928); "Más sobre los orígenes de la Internacional en Buenos Aires. Documentos nuevos e inéditos", Suplemento Quincenal de La Protesta (Buenos Aires, 3 de septiembre de 1928). 
Report concerning the International Congress in Bern. We ask you to please send us some good Italian newspapers". 23

Another letter from Montevideo sent in February of 1877 to La Social of Mexico noted, "By way of our sister Spanish Federation, we ask for admission to the Ix Universal Congress of Workers in the name of the Montevideo Federation, which counts six organized trades, five sections, and two thousand permanent members." The sign-off now read: "Health, Anarchy, and Fraternity". ${ }^{4}$ Guillaume confirms the existence of that letter: the 9th General Congress of the International, which met in Verviers from 6 to 8 September 1877 , accepted the request and "the Federation of Montevideo was [...] received in the International". ${ }^{25}$

On September 1st, 1878, the sections held a "general Assembly" which voted the creation of the "Regional Federation of the Oriental Republic of Uruguay of the International Workingmen's Association". The assembly also approved a Declaration of Principles, a Statute, some Regulations, a pamphlet including the Manifesto, Statutes of the International penned by Marx (approved at the Geneva congress), the Statutes modified by the Geneva Congress of 1873 . The Statutes and Regulations approved by the Montevidean Federation, which defined the functions of the committees, was quickly edited. The Federation's organizational characteristics were twofold: it had a territorial character and a functional character, including administration, propaganda, organization, and discussion. ${ }^{26}$ These were preceded by a "Prologue" in which the critique of labor exploitation fall back onto the "monopoly" of Capital: the capitalist society was presented as "prisoner to monopoly and, therefore, to privilege and injustice." The solution extolled by the International was "collective property in the means of production" so that each individual belonging to mankind be able to work with his/her own means and receive the complete product of his/ her labor, without falling prey to an exploiter. Once this becomes true, "Truth, Justice, Morality will be the base of human relations". ${ }^{27}$ More than a mere political pamphlet, it was a membership book. The first page was reserved for the name of the member, together with the signatures of the President, of the

\footnotetext{
23 Ibid., vol. 4, p. 193.

24 Valadés, "Sobre los orígenes", pp. 87-88.

25 Guillaume, L'Internationale, vol. 4, 258.

26 Carlos Zubillaga, Pan y trabajo. Organización Sindical, Estrategias de Lucha y Arbitraje Estatal en Uruguay, 1870-1905 (Montevideo, 1996), p. 44.

27 Carlos M. Rama, "Los internacionalistas de 1870", Nuestro Tiempo 2 (Montevideo, 1955), pp. $115^{-121 .}$
} 
secretary, and of the member himself/herself. The last page was reserved for the registration of memberships dues.

In 1878, a newspaper entitled El Internacional. Órgano de las clases trabajadoras was started in Montevideo. Published under the motto of "Justice, Morality, Work," it was the organ of the Regional Federation of the Oriental Republic of Uruguay. It had only two issues. In the first issue one could read: "The eternal question of labor and capital, the emancipation of workers and the reduction of capitalist power cannot be answered but by the victory of those who today endure the ominous yoke of power, in all places of the world."28

As in Mexico, the International effectively attracted those migrants and creole workers in order to create the first worker's central organization. According to Rama, the Internationalists were the first to organically connect the working class of Montevideo with socialist ideas and the future of the international working class. In addition, a continuity can be traced between the Regional Federation of the Oriental Republic of Uruguay (of the International) and the Local Federation of the Workers of the Uruguayan Region from 1885, founded a decade later, and even with the Regional Uruguayan Worker's Federation (FORU) set up in 1905. For, Rama affirms, they had "the same form of organization, the same style of tactics regarding worker's struggle and even the same ideological orientation, deriving from anarchism in its Proudhonian and Bakuninist forms. The model is borrowed from workers' movements with a libertarian inclination from Spain and Italy, and frequently it was the Spanish and Italians, when not Frenchmen, who stood as leaders of this tendency". ${ }^{29}$

\section{The Failed Attempts of Communards in Buenos Aires}

Across the Rio de la Plata, in Argentina, the Buenos Aires Typographic Society had established ties with the Federal Council of the Spanish Region as early as 1870. They received the first publications of the International through this connection. ${ }^{30}$ Two years later, a letter sent from Buenos Aires dated 1oth February

28 El Internacional, 1 (Montevideo, 12/5/1878).

29 Carlos M. Rama, “Obreros y anarquistas", Enciclopedia Uruguaya, 32 (Montevideo, 1969), pp. $25^{-26 .}$

$30 \quad$ Until the advent of modern studies of Ricardo Falcon, La Primera Internacional y los orígenes del movimiento obrero en Argentina. 1857-1879 (París, 1980); "Documentos para la historia de la Primera Internacional en el Río de la Plata", Apuntes para la historia del movimiento obrero y antiimperialista, 2, (París, 1980), the references to the history of the First International in the Rio de la Plata were very remote: Jose Ingegnieros, "La Internacional en Sud América (Datos que servirán para la historia del socialismo)", Almanaque de La 
1872 signed by a so-called Émile Flaesch was sent to the General Council in London, announcing that, days earlier, twenty-six citizens had founded the Section Française de l'Association Internationale des Travailleurs and requesting its affiliation with the IWMA. A triangular stamp read in the middle, Association Internationale des Travailleurs; on one side Section Française, on the other Pas de devoirs sans droits, pas de droits sans devoirs. ${ }^{31}$ A postscript dated from the following month announced that the section now had seventy members and predicted that "the International would succeed in Buenos Aires as soon as it was well-known."

On 14 April 1872, Flaesch sent from Buenos Aires another, even more enthusiastic letter:

At the present date 89 of us have registered; 60 new members have been presented and will be accepted at the next session. Many worker societies will soon ally themselves to us. The country's newspapers, fierce enemies of the Association from afar, are now silent since they know it from close up. The representative from France has declared himself amazed by what he calls our audience. The International is in all conversations. Speeches in favor and against us have been pronounced in the masonic lodges. ${ }^{32}$

Its immediate goal was the publication of a socialist newspaper, but lacking information on the International, they expressed their desire to correspond with their European counterparts: "We beg you, citizens, keep in mind, in one of your correspondences, to please tell us how to communicate with the Parisian Federation and, if they exist, other sections of the Association in South America, and in which cities". 33

A third letter from Fleasch on 16 July 1872 spoke of exponential growth: "We reach today the number of 273 and we hope not to stop there." He mentioned too the creation of the Italian section, whose nucleus was already important enough to separate itself from the French section. Flaesch assigned an

Vanguardia para 1899 (Buenos Aires, La Vanguardia, 1889); Mario Bravo, "La Asociación Internacional de los Trabajadores en la América Latina", Crítica Social (Buenos Aires, 21/1/1926), pp. 3-4; Faustino Jorge, "La Asociación Internacional de los Trabajadores en la Argentina”, Argumentos, 2 (Buenos Aires, 1938).

31 Horacio Tarcus, Marx en la Argentina. Sus primeros lectores obreros, intelectuales y cientifi$\cos$ (Buenos Aires, $2^{\mathrm{a}}$ ed. 2013,), p. 496.

32 Flaesch to General Council, Buenos Aires, 4/14/1872, in Horacio Tarcus Marx en la Argentina, p. 497 .

Tarcus, Marx en la Argentina, p. 498. 
enormous importance to this section: "Here, the Italians constitute the majority of the foreign population." 34

Finally, an anonymous author calling themselves the "Fondateur de l'Internationale à Buenos Ayres" reported the creation of another section that did not "sincerely" abide by the official branch, which "could perhaps end by way of harming the Association." But it's probable that the Communards of Bakuninist orientation that had arrived in Buenos Aires had joined mutualist and resistence societies together without forming a bona fide section. The letter sent by A. Juanes to the Mexicans brothers of La Social said: "From Buenos Aires, I return disconsolate: only among the artisan bakers have I found an atmosphere favorable to the development of resistance societies" ${ }^{35}$ Libertarian groups would not appear in Buenos Aires until the end of the decade, in 1879.

Shortly thereafter a Spanish section emerged. According to a letter of Aubert (another exile who appears as the new "Secrétaire des Sections de B. Ayres") to Jean Latraque (an ex-Communard exiled in San Sebastian, Spain):

Today, there exist in Buenos Aires three sections of the International, based on linguistic differences: the French section, and the Spanish and Italian sections, which were formed later. Each section has its own central committee, and questions of general interest are addressed by a federal council composed of six members (two for each section). I will not speak of the difficulties that it had to overcome at the beginning. ${ }^{36}$

José Ingenieros tells us that a fourth section of the International appeared in Cordoba around 1874; but it was probably very small and little evidence of its existence has been recorded. ${ }^{37}$

The Argentine section obtained the recognition it had requested. Le Moussu the Communard refugee who was the corresponding secretary for Latin America, sent an official notification from London to Buenos Aires on 1 July 1872. According to the historian Ermolaiev, "he enclosed twelve copies of the Statutes of the International". ${ }^{3}$

34 Ibid., p. 499.

35 Valadés, "Sobre los orígenes", p. 84.

36 Aubert to Latraque, Buenos Aires, 3/23/1873, in Tarcus, Marx en la Argentina, p. 502.

37 José Ingenieros, “La Internacional en Sud América (Datos que servirán para la historia del socialismo)", Almanaque de La Vanguardia para 1899 (Buenos Aires: La Vanguardia, 1898) pp. 24-26, p. 25 .

38 V. Ermolaiev, "Surgimiento de las primeras organizaciones obreras", in La Primera Internacional y el triunfo del marxismo leninismo (Buenos Aires, 1964), p. 262. Originally appeared in Voprosy istorii, 1, (Moscu, 1959), pp. 81-97. 
Apart from these letters, there are unfortunately no other documents concerning the Internationalists in Buenos Aires. No file of its newspaper, El Trabajador, is known to have been preserved. Regarding the division between "Bakuninists" and "Marxists", the Argentine section appears to have been aligned with the latter. For Abad de Santillán, "above all, the French section had to have been Marxist or influenced by the followers of Marxism".39 The contrast with Montevideo is noteworthy: Juanes returned from Buenos Aires "disconsolate" concerning the power of the "authoritarians." He added: "Ah! The jackasses need a whipping." A month later, Galcerán, the secretary of the Uruguayan section, wrote to his Mexican counterpart: "We are preparing a newspaper that will be called El Obrero Federalista in order to combat the authoritarians, who have seated royalty in Buenos Aires".40

The Buenos Aires Internationalists can be cautiously described as "Marxist" in the same way as their Mexican and Uruguayan counterparts may be called "Bakuninist"; the same caveats apply. In fact, their "Marxism" was more a global orientation toward political action and a proclaimed loyalty to the Council in London, with whom they had had contact, than an acceptance of Marx's theories, which they undoubtedly did not know. Nettlau's hesitations make sense when he writes, "the movement in Buenos Aires was rather workerist and socialist in general".41

Among the delegates attending the fifth general Congress which took place at The Hague in September 1872, was Raymond Wilmart. This rebellious child of Belgian aristocrats had been recruited into the International by Paul Lafargue in Bordeaux. According to the proceedings, in which he appears under the pseudonym of Vilmot, he sided with the "Marxists" to vote for the expulsion of Guillaume and Bakunin. It was in this congress that participants were informed of the "branching out to Buenos Aires, Australia, and New Zeeland" (Flaesch's letters had been received some time before). Once the Bakuninists had been expelled, the General Council resolved to send a delegate to Buenos Aires to explain and defend the line established at The Hague and to counter the possible reactions of the dissidents. This task was entrusted to Wilmart. In three successive letters to Marx - whose originals have been preserved at the Marx-Engels Papers of the IISG and which I've reproduced in my Marx in

\footnotetext{
39 Diego Abad de Santián, El movimiento anarquista en la Argentina. Desde sus comienzos hasta el año 1910 (Buenos Aires, 1930), p. 16.

$40 \quad$ Valadés, "Sobre los orígenes", p. 84.

41 Nettlau, "La Internacional en Buenos Aires", p. 17.
} 
Argentina - Wilmart informed him of the local situation, giving vent first to his enthusiasm and then to discouragement. ${ }^{42}$

On 13 May 1873, he wrote in his first letter: "I have placed four series and I've saved one for myself." He was probably referring to the French edition of Capital that was then being published in installments. Wilmart had begun distributing it in Buenos Aires. Wilmart also dismissed any anarchist influence in the Argentine section: "There is no official correspondence with the Jura federation." In fact, the opposite was true: "The grouping of the three sections is far from anarchism - excessively disciplinary." In any case, Wilmart asked Marx for briefings on several Communards who were members of the Buenos Aires section and whom he suspected to be Blanquist activists. Among these were many Frenchmen, "remainders of the shipwreck of the Paris Commune," along with Swiss, Italians, and even representatives of the first wave of French migration who had participated in the Revolutions of 1848. They had "little energy", said Wilmart, who thought their educational and mutual aid project were "unrealizable". The young revolutionary progressively became exasperated: "Time is lost in these discussions on the inevitable questions of regulation." ${ }^{43}$ Wilmart intervened energetically in favor of political action at the risk of appearing, among those who were older than him, as "a little exalted." Finally, Wilmart reported that he had been designated member of the board of administrators of the newspaper El Trabajador, but was no longer a member of the editorial team, which might be an indication of mistrust. Wilmart sent several collections of El Trabajador to London and asked for copies of European newspapers. Just before he signed off, he made a quick observation about the immeasurably better living standards in the country, would make it appear to many Europeans as a "refugium peccatorum." Wilmart was beginning to find some attractiveness in the semi-barbarous land of Argentina.

Two weeks later, on 27 May 1873, his discouragement had become perceptible. Although "a proposal had been voted at the Federal Council to pave the way for creating a federation of guilds," things advanced "always very slowly." It took a lot of time to publish the newspaper, the mutualist spirit predominated, and instead of struggling over propaganda and political action, the sections indulged in mutualist and educational activities. Wilmart concluded that, apart from some French or Spanish exiles who were already politically conscious when they had arrived, the Argentina of 1873 was not yet ready for international socialism:

Tarcus, Marx en la Argentina, pp. 504-511. See also: Horacio Tarcus, Diccionario biográfico de la izquierda argentina. De los anarquistas a la "nueva izquierda". 1870-1976 (Buenos Aires, 2007). 
I am beginning to believe that there's nothing to do with the elements here. There are too many possibilities to become a small owner and to exploit recently-arrived workers to think about acting in a certain way. ${ }^{44}$

When responding to his previous letter, Marx had obviously insisted on possible ties with the Bakuninists, since Wilmart reiterated: "there are no reasons to believe in the existence of any correspondence with the 140 members of the Jura federation." But his optimism of a few days earlier concerning the circulation of Marx's magnum opus had disappeared:

Until now, nothing has been said about Capital and I think that nobody has finished reading it, since nobody takes the time to think in this country. 45

His depiction of the country's political backwardness was devastating:

In this country politics as a whole boils down to personalities and, in Europe, they would barely believe that there are not only rivalries between the States but also between the provinces. ${ }^{46}$

Wilmart did not draw this conclusion from political struggles in Argentina, but rather from the confrontations between caudillos and the masses mobilized by the "magic of names." His perspective did not differ much from Marx's when the latter wrote "Bolívar." In this context, Wilmart was favorable to the consolidation of a unified and centralized State, and indeed, after the failure of the International, he enlisted in the army as a volunteer to fight against the caudillo forces in the province of Entre Ríos. Wilmart also painted a large fresco of "barbarism" in Argentina:

Without the affluence of foreigners, no progress would be possible, no one would know anything but how to ride horse. ${ }^{47}$

On 14 June 1873, Wilmart sent Marx a final letter in which he described the irrepressible downturn in the Argentine sections:

\footnotetext{
44 Ibid., pp. 507-508.

45 Ibid., p. 508.

46 Ibid.

47 Ibid.
} 
Things are going poorly here: empty sessions, lack of goodwill. Three more have just left, the daily has not appeared in the last month. The issue that was supposed to come out tomorrow, will not appear before the 2oth. We're lacking in funds and we must have paid roughly eight. ${ }^{48}$

Wilmart did not try to hide his uneasiness and, even worse, he saw some similarities with the crisis of the Spanish Federation. The International was now fighting against the current: "We should not ever become discouraged, but we need much more patience to blow on the ashes of those who do not want to spark again. If I've been well informed, Spain is not going well and I have the impression that it is the same thing everywhere." Most likely, the Argentine section of the International did not outlive its vegetative state after 1874 .

Considering his mission was now over, Marx's emissary decided to stay in Argentina for good. Because he had been born in elite circles, it did not take Wilmart long to connect with the elite in Argentina, becoming a reputed lawyer in the Porteño forum, and later a professor at the Law School and author of numerous works. He became a moderate voice within Argentine socialism and an advanced voice in jurisprudence, a partisan of international tribunals and a defender of the rights of workers and women.

In 1875, a brief attempt to give a new start to the Section Française de Buenos Ayres must have taken place. In March, several dailies reported that a police operation had broken into the second floor of a tenement house in that city and arrested "twelve members of the International Society of Workers, the recently founded French section of Buenos Aires." These arrests were the result of an investigation into the causes of an incident which occurred on the afternoon of 28 February, when an exchange of shots took place as an ecstatic multitude approached the College of Salvador where an anticlerical meeting had been organized by Argentine masons. ${ }^{49}$ On 20 April the judge on duty, Damián Hudson, decided to drop the case and released the men who had been detained. The Internationalists had been imprisoned for thirty-seven days.

Thanks to the judicial process, important direct documentary sources, including the session's minutes, have been preserved. ${ }^{50}$ Of the eighteen members of the new Section, sixteen were recently-arrived Frenchmen. Just like those who had formed the first French Section, they were most likely

\footnotetext{
48 Ibid., p. 511.

49 Hilda Sabato, La política en las calles (Buenos Aires, 1998), p. 8.

50 Hilda Sabato, "Sección francesa de Buenos Aires de la Asociación Internacional de Trabajadores: documentos para una historia. Selección y nota preliminar", Estudios del trabajo, 14 (Buenos Aires, 1999).
} 
ex-Communards from the south of France who had escaped repression. Official transcripts tell us that many were artisans: two pastry makers, two bakers, a shoemaker, a painter, a carpenter, a printer, a photographer, a machinist, a cleaner, a tailor, a bookkeeper, and a journalist. The Dictionnaire biographique du mouvement ouvrier français offers no information about the majority of them, since, like the exiles involved in the previous attempt, they were young rank and file militants, unknown until the Commune.

The first formal session was held on 14 February 1875 . They debated then the character of the association. The journalist Stanislas Pourille, a former elected Commune member under the name of Blanchet, presided over the meeting, and a Blanquist, Job, acted as secretary. At their next meeting, they approved a regulation stipulating that to be admitted into the Section, it was "necessary to justify one's quality as a worker or present evidence of one's civic and social virtues." "All those living off usury, stock market business, all those belonging to a religious order, or exploiting gambling or prostitution establishments" would be barred from joining.

The third assembly perilously coincided with the anticlerical meeting. The meeting addressed an assembly of workers. They approved a manifesto redacted by Pourille that was printed in French, Italian, and Spanish, and was to be sent to newspapers for publication. As in the Manifesto of Montevideo, a certain classist perspective underlaid its critique of the "international association of parasites, that is to say, the class that lives and enjoys the fruits of the earth and industry at the expense of those who work and suffer."51

Nevertheless, disregarding the emphasis put by the International on the constitution of the working class as a political party, an ethical dimension was here emphasized: it was a call for unity, for the fraternity of all the victims of poverty. The appeal to class solidarity gave way, a few paragraphs later, to an appeal to individuals, to "men poor and inspired by the love of liberty, equality, and fraternity." Its call to them to get rid of "egoism, avarice, usury, libertinage, and prostitution" was closer to the Christian socialist or romantic socialist discourses than to the rhetoric of the International. Moreover, the motto chosen by Pourille ("all for one, one for all") is more reminiscent of the romantic socialism of The Three Musketeers than of an appeal to the political unity of the working class in order to seize power. When the newspaper Le Revolutionnaire was launched a few months later in Buenos Aires, Pourille included among his references Fourier and Cabet, Mazzini and Garibaldi, Proudhon and Blanqui, but neither Marx nor Bakunin. ${ }^{52}$ As we know, however, the manifesto was

51 Tarcus, Marx en la Argentina, p. 110.

$5^{2} \quad$ Ibid., p. 118. 
never printed and the Internationalists never called a public meeting. In the middle of their fifth session on Sunday, 3 March 1875, they were surprised by a police raid. This second attempt did not survive the unpleasant experience of trial and prison.

How may this failure of the Argentine sections be accounted for? First, both attempts were to some extent the by-product of the Paris Commune. But after the fall of the Commune, the International entered, as Molnar called it, its period of "decline." ${ }^{33}$ The porteñas sections were in this respect born at the wrong time, at the moment when working class internationalism was beginning to ebb in Europe and in North America.

Secondly, the organizational model and political actions of the International presupposed the existence of a proletariat whose formation had barely begun in the Buenos Aires of 1870, where a new layer of urban workers of predominantly artisanal and mostly immigrant origin were consolidating and when starting to rehearse forms of organization of a mutualist nature. During this decade and the next, the possibilities and expectations of upward mobility were still important. The mainstream press and elite men boasted about the absence of the Social Question in Argentina.

Third, we should also consider that the conceptions and socialist values of the French internationalists were too much at odds with the liberal, individualist, and competitive ideology that dominated civil society in Argentina at that time. Aubert's and Wilmart's letters give us the image of a small nucleus of self-sacrificing men pitted against the attacks of a few and the disdain of the rest. Moreover, their socialism had a low grade of coherence. The only "political cadre," to use a twentieth-century term, with any knowledge of Marxism was Wilmart. But his failure to get any Communards to read the early chapters of Capital is telling. In Europe, too, it would be "a complicated reading," not only for the militant workers but also for many of the leaders. ${ }^{54}$

Finally, as with any relatively socially isolated group, there existed a climate of suspicion, rivalry, and division. The requests to London for reports from Flaesh and Wilmart were symptomatic in this respect. According to the testimony of Ingenieros, the internationalists "wasted their time and activity in futile quarrels without showing their work outside a narrow circle of

53 Miklos Molnar, El declive de la Primera Internacional (Madrid, 1974).

54 Franco Andreucci, "La difusión y vulgarización del marxismo", in Hobsbawm et al., Historia del marxismo, 8 vol. (Barcelona, 1979-1983) vol. 3, p. 67 . 
secretaries".55 As opposed to the cases of Mexico City and Montevideo, the sections of the International did not leave much of an imprint in the working classes of Buenos Aires. Its cycle was to begin later, in the dual form of anarchism and socialism, with the celebration of May Day in 1890. But that is another story.

55 Ingenieros, “La Internacional en Sud América”, p. 25. 